\title{
Institutional Investors, Stock Repurchases and Information Asymmetry
}

\author{
Ricky W. Scott ${ }^{1}$ \\ ${ }^{1}$ Donald R. Tapia School of Business, Saint Leo University, Saint Leo, Florida, USA \\ Correspondence: Ricky W. Scott, Donald R. Tapia School of Business, University Campus - MC 2011, PO Box \\ 6665, Saint Leo University, Saint Leo, FL 33543-6665, USA. Tel: 1-352-588-8304. E-mail: ricky.scott@saintleo.edu
}

Received: July 2, 2014

doi:10.5430/ijfr.v5n4p39

\author{
Accepted: August 6, 2014 \\ Online Published: August 24, 2014 \\ URL: http://dx.doi.org/10.5430/ijfr.v5n4p39
}

\begin{abstract}
This paper seeks to determine if institutional investors influence stock repurchases. Specifically, this study tests whether institutional investors encourage stock repurchases in firms with high information asymmetry. Firm and year fixed effect regressions examining the effect of changes in institutional investor levels to subsequent changes in stock repurchase levels are used. For robustness, regressions are run using difference-GMM regressions and regressions for different time periods on the same relationship. I find that increased institutional ownership leads to increased stock repurchases and this relationship is stronger in firms with higher information asymmetry. Results indicate that institutional investors encourage management to increase repurchases so as to exploit their informational advantage over less informed investors about the true value of the firm. Institutions are the dominant force in U.S. stock ownership. The results in this paper indicate that institutional investors are using their informational advantage in firms that are difficult to value in an attempt to boost their return at the expense of other less informed shareholders.
\end{abstract}

Keywords: institutional investors, payout policy, repurchases, dividends

\section{Introduction}

Corporate payout policies have been a subject of interest for a number of years even though payouts should theoretically not have an effect on shareholder wealth unless tax consequences are considered (Lintner, 1956; Miller \& Modigliani, 1961; Poterba \& Summers, 1984). Likewise, shareholders should be indifferent between repurchases and dividends except for tax consequences. Black (1976) questions why firms pay dividends and this question has been echoed repeatedly. In fact, a copious amount of research has been done which expands on this question by trying to determine why firms make stock repurchases and why do they choose one form of payout over the other.

Corporate payout decisions may be influenced by shareholders such as institutional investors. If this is true, then the effect that institutional investors have on payout policies may change with the level of institutional ownership. Institutional ownership of all U.S. stocks has grown to over $70 \%$ of the shares of U.S. corporations (Gaspar, Massa, Matos, Patgiri, \& Rehman, 2013). Institutional investors are also important stockholders internationally as demonstrated by the fact that institutional investors hold 50 to 60 percent of large listed European companies (Brossard, Lavigne, \& Sakinç, 2013). It seems logical that if institutional shareholders hold a preponderant level of ownership in a corporation that they could have an effect on that corporation's payout policies. (Becht, Bolton, \& Röell, 2003) discuss several types of corporate decisions in which research supports the assertion that institutional investors influence corporate policies.

Institutional investors have special characteristics that affect their ability to influence management to make decisions that are beneficial to shareholders. Institutional investors are considered more informed and influential than an average investor. This should make them better representatives for shareholders' interests. Conversely, institutional investors are agents that may act in their own interest instead of the interest of their principals.

Elyasiani \& Jia (2010) determine that institutional investors typically participate in active monitoring of management, passive monitoring, cooperate with management even if it hurts other shareholders, or a combination of these monitoring tactics. Institutional investors typically are better informed and have larger stakes than other investors which leads to increased incentives and ability to actively monitor management in a way that will improve firm performance (Shleifer \& Vishny, 1986). Cornett, Marcus, Saunders, \& Tehranian (2007) find evidence that some 
institutional investors that have an outside business relationship with management cooperate with management to their mutual benefit at the expense of other shareholders.

Barclay \& Smith (1988) and Brennan \& Thakor (1990) construct an adverse selection theory which asserts that larger, better informed shareholders will prefer repurchases to dividends. In this theory, larger investors have a greater incentive to become informed and informed shareholders know more about a repurchasing company's true value than other investors. This knowledge can be used to profit at the expense of less informed shareholders. If the firm is undervalued, informed investors will not offer their shares for repurchase. If the firm is overvalued, informed investors will offer their shares for repurchase. Other less-informed investors don't know enough about the company to judge if it is undervalued or overvalued. Therefore after repurchases are completed, informed investors will own proportionally more of undervalued firms and proportionally less of overvalued firms. In both cases, informed investors gain at the expense of other investors.

Institutional investors are considered to be better informed and generally have larger holdings in a firm than individual investors. Therefore, according to the adverse selection theory, institutional investors should prefer repurchases. Additionally, repurchases should become a more advantageous method of payout for institutional investors as the level of information asymmetry between informed and uninformed investors in a firm grows. The prediction that I test based on the adverse selection theory is that higher institutional investor ownership leads to a higher level of repurchases, especially in firms with higher asymmetric information.

My results provide support for the adverse selection theory. I find that changes in institutional ownership have a positive relationship to subsequent stock repurchase activity, especially in firms with high information asymmetry. It could be argued that this indicates that institutional investors encourage higher repurchases for tax reasons, but that would not explain why institutions encourage repurchases more in firms with higher information asymmetry. It appears that institutional investors are using their information advantage to profit at the expense of other less informed investors thus providing evidence for the adverse selection theory.

Institutional investors own the preponderance of U.S. public corporations. Additionally, there is substantial evidence indicating they are superior monitors. In this paper, I investigate empirically the relationship between institutional investors, information asymmetry, and repurchase policy. The primary contribution of this paper is that I determine that institutional investors encourage repurchases primarily in firms in which they have an informational advantage.

\section{Literature Review}

Grinstein \& Michaely (2005) conduct an investigation into the relationship between institutional investors and repurchase policy. They find that institutions prefer firms that repurchase shares, especially if they regularly repurchase. They also find that institutional investors do not influence repurchases. Their latter result is at odds with my findings.

I can offer some explanations for the discrepancies between their results and mine. One likely explanation is that my definition of repurchases differs from theirs. My definition is similar to that used by Fama \& French (2001). I define repurchases as the dollar amount of stock repurchases minus the dollar amount of stock issues. I reason that if a firm repurchases a dollar's worth of stock in the same time period as the firm issues a dollar's worth of stock, then the firm has not really repurchased any shares at all. I also contend that the concept of negative repurchases is not valid for the purposes of my investigation. Therefore, if the value of stock issued is more than the value of that repurchased, I define repurchases as being equal to zero. In contrast, Grinstein and Michaely do not subtract stock issues from stock repurchases. They do not offer an explanation for this definition, but it is likely that their reasoning follows that expressed by Grullon \& Michaely (2002) who argue that new equity issuance and stock options used for payment to labor should not be included in repurchase calculations. Another possible explanation for the difference in our results is that they only include firms in their sample that pay dividends and I include all firms without regard to their payout policies.

Institutional investors have been known to shape corporate policies directly through shareholder proposals and proxy votes and indirectly through publicity generation and the threat of selling their shares (voting with their feet) thus depressing stock share price. In a survey of CFOs, Graham, Harvey, \& Rajgopal (2005) find that institutional investors are important because they can affect a firm's market capitalization by buying or selling the stock en masse. Additionally, the CFOs recognize that institutional investors can affect their firm's future cost of capital. These results indicate that management recognizes the importance of institutional investors. Gillan \& Starks (2007) provide evidence that institutional investors can instigate governance changes that better discipline management through the simple act of selling shares. In a study of companies from 23 countries, Aggarwal, Erel, Ferreira, \& Matos (2011) 
find that higher institutional ownership increases the likelihood that poorly performing Chief Executive Officers (CEOs) will be terminated and that firm valuation will improve. Institutional investors help to control earnings management (Hadani, Goranova, \& Khan, 2011).

The presence of institutional investors has been found to have an effect on payout policies in several studies. Moser (2007) offers evidence that management reacts to the wishes of institutional investors by showing that firms increase repurchases as a percentage of total payout as tax-disfavored (by dividend payments) institutional ownership increases. Conversely, repurchases decrease as tax-favored institutional ownership increases. Sulaeman (2008) proposes that management reacts to institutional investors' leverage preferences by using repurchases to increase firm leverage if the firm's current leverage is below the aggregate preference of its institutional shareholders. De Cesari, Espenlaub, Khurshed, \& Simkovic (2012) find that the information advantage enjoyed by institutional owners reduces opportunities for companies to repurchase stock at bargain prices. Desai \& Jin (2011) offer evidence that management alters dividend policy to cater to institutional shareholders.

Bartov, Krinsky, \& Lee (1998) find in a study of matched firms that firms with higher levels of institutional holdings repurchase more shares. They note that many prominent institutional investors, notably Fidelity, have openly expressed their preference for stock repurchases over dividends. They also explain that this preference is logical since institutions may be acting as good stewards for their investors whose income is taxable by reducing their taxes through the substitution for repurchases in place of dividends.

Renneboog \& Trojanowski (2011) report a result that is inconsistent with tax-clientele explanations for payouts. They find that tax-exempt financial institutions in the U.K. prefer repurchases over dividends. On the other hand, this result is consistent with the adverse selection theory because the tax-exempt institutions' informational advantage over other less informed investors could allow them to profit from repurchases at the expense of the other investors.

The adverse selection theory of Barclay \& Smith (1988) and Brennan \& Thakor (1990) asserts that stock repurchases create an opportunity for more informed shareholders to profit at the expense of less informed shareholders. In this theory, more informed investors can more capably ascertain the true value of the firm. If the firm is undervalued, more informed investors will not offer their shares for repurchase. If the firm is overvalued, more informed investors will offer their shares for repurchase. Less informed investors don't know enough about the company to judge if it is undervalued or overvalued.

Since the managers of a firm should be at least as well informed as institutional shareholders, the adverse selection theory relies on the presumption that managers will sometimes knowingly offer to repurchase shares that are overvalued. This is counterintuitive behavior that implies management is intentionally reducing the value of their firm. Yet, there is evidence that management engages in such behavior. D'mello \& Shroff (2000) find that insiders are net sellers in the year before repurchases of overvalued firms, while they are net buyers in the year before repurchases of undervalued firms. This evidence indicates that insiders are more knowledgeable about the true value of their firm and that they do sometimes conduct repurchases even though they are aware their firm is overvalued. D'mello \& Shroff (2000) provide one possible explanation for this behavior. They note that repurchases have been used to defend against hostile takeovers by increasing leverage and reducing the liquidity of the stock. In this case, management benefits from repurchasing overvalued shares because they are more likely to retain their lucrative executive positions if the hostile takeover does not occur.

A thorough review of corporate payout policy can be found in DeAngelo, DeAngelo, \& Skinner (2009).

\section{Hypotheses}

The adverse selection theory predicts that institutional investors will prefer repurchases if they are more informed than other investors about a firm's true value. Previous research indicates that institutional investors are better informed than other investors. For example, Bennett, Sias, \& Starks (2003) find that institutional investors have an informational advantage over other shareholders which varies with firm characteristics and information asymmetry. Institutions also have an informational advantage in newly public firms and seasoned equity offerings which is largely the result of better analysis of publicly available information (Field \& Lowry, 2009; Chemmanur, He, \& Hu, 2009). This leads to my first hypothesis:

H1: Higher institutional investor ownership leads to a higher level of repurchases.

According to the adverse selection theory, institutional shareholders prefer repurchases because their informational advantage allows them to ascertain the value of their shares more accurately than other shareholders. If a firm is difficult to value accurately, it is said to have higher information asymmetry (a larger information gap between 
informed and uninformed investors). Therefore, if the adverse selection theory holds, institutional investors should favor repurchases more in firms that have a higher degree of information asymmetry.

If institutions prefer repurchases equally in all firms, this could provide support for the adverse selection theory, but it also may provide evidence that institutions prefer repurchases for other reasons. For example, (Bartov et al., 1998) find in a study of matched firms that firms with higher levels of institutional holdings repurchase more shares. They argue that institutions prefer repurchases over dividends to lower the tax burden on their taxable shareholders. Their reasoning can explain a preference for repurchases by institutions, but unlike the adverse selection theory, this tax effect should not be more pronounced in firms with higher information asymmetry. My next hypothesis is based on the adverse selection theory:

H2: The relationship between higher institutional investor ownership and higher repurchase levels will be stronger in firms with higher asymmetric information.

The relationship between institutional investors and repurchase policy is endogenous. Therefore, it is not sufficient to determine that there is a positive relationship between institutional investors and the percentage of total payout which is made up of stock repurchases. Causality is also important. The causal relationship in the substitution hypothesis requires that institutional investors have a positive influence on the percentage of total payout which is made up of stock repurchases.

\section{Data, Methods, and Summary Statistics}

\subsection{Data}

I begin with yearly $(1990$ - 2005) institutional and insider ownership data for each firm from CDA / Spectrum Compact Disclosure. I exclude utilities and financial firms because they are highly regulated. I then merge this ownership data with firm characteristic data from Compustat. The final sample includes 10,668 firms and 79,890 firm-years. Firms with missing data or data from too few firm-years to perform required analysis are excluded from that analysis.

I measure stocks repurchases in dollars and scale them by the book value of assets. Repurchases are also measured in dollars and defined as stock repurchases minus stock issues. If stock issues exceed repurchases, the repurchase amount is defined as zero. Changes in repurchases are measured as the repurchases of the current year less repurchases from the previous year, scaled by the previous year's book value of assets.

Fama \& French (2001) find that firm profitability, size and growth opportunities are related to payouts. They also find that dividends trend with time. As a result, I use variables to control for differences across firms in these characteristics and for time trends in payouts. Profitability is represented by earnings before interest and taxes divided by total assets. Size is controlled for by using log of revenue and $\log$ of market value. Growth opportunities are controlled for by using $q$. I follow Dlugosz, Fahlenbrach, Gompers, \& Metrick (2006) by calculating $q$ as the ratio of the market value of assets to the book value of assets where market value is calculated as the sum of the book value of assets and the market value of common stock less the book value of common stock and deferred taxes. All regressions use dummy variables for each year to control for time effects.

DeAngelo, DeAngelo, \& Stulz (2006) argue that a company's life-cycle stage as proxied by its earned/contributed equity mix has an impact on payouts. Therefore I use the company earned/contributed equity mix defined as retained earnings to the book value of total equity as a control variable. (Banerjee, Gatchev, \& Spindt, 2007) find that firm stock turnover is related to payouts so I include it as a control. I include the ratio of firm debt to assets as a control because Jensen (1986) argues that debt can substitute for payouts as discipline for management.

Payouts are typically paid from free cash flow. Many measures of free cash flow deduct payouts from cash flow. I do not make this adjustment in my measure of free cash flow because it complicates the analysis of the effect of free cash flow on payouts. I use net income plus depreciation and amortization minus capital expenditures to measure free cash flow and divide this value by book value of assets to provide scale. Table 1 provides detailed definitions of all variables.

\subsection{Methods}

It is important to my analysis to determine is if institutional investors influence repurchases. If repurchases influence institutional investors, this can muddy my results. Therefore, I need to use a regression methodology which establishes causality and controls for endogeneity. Initially, I attempted two-stage least squares' regressions with instrumental variables. Unfortunately, I was not able to find instrumental variables for my data sample which satisfied statistical and conceptual criteria. 
Table 1. Variable definitions

\begin{tabular}{|c|c|c|}
\hline Variable & Description & Definition \\
\hline \multicolumn{3}{|c|}{ Panel A: Summary Statistics and Correlation Table Variables } \\
\hline$N$ & Number of Firms & The number of firms. \\
\hline Inst & Institutional Ownership & The fraction of shares owned by institutions. \\
\hline MktCap & Market Capitalization & The dollar market value of common stock in millions. \\
\hline LifeCycle & Firm Life-cycle & The ratio of retained earnings to total equity. \\
\hline$q$ & Investment Opportunities & Market value of assets to the book value of assets \\
\hline CashFlow & Free Cash Flow & Free cash flow to total assets. \\
\hline Div & Dividend Ratio & Dividends to book value of assets. \\
\hline Payout & Payout Ratio & Total payout divided by book value of assets. \\
\hline Repurch & Stock Repurchase Ratio & Stock repurchases to book value of assets. \\
\hline PayIncr & Payout Increases & $\begin{array}{l}\text { The percentage of firms which increased their total } \\
\text { payout per share. }\end{array}$ \\
\hline PayDecr & Payout Decreases & $\begin{array}{l}\text { The percentage of firms which decreased their total } \\
\text { payout per share. }\end{array}$ \\
\hline RepIncr & $\begin{array}{l}\text { Stock Repurchase } \\
\text { Increases }\end{array}$ & $\begin{array}{l}\text { The percentage of firms which increased their } \\
\text { repurchases per share. }\end{array}$ \\
\hline RepDecr & $\begin{array}{l}\text { Stock Repurchase } \\
\text { Decreases }\end{array}$ & $\begin{array}{l}\text { The percentage of firms which increased their } \\
\text { repurchases per share. }\end{array}$ \\
\hline \multicolumn{3}{|c|}{ Panel B: Regression Dependent Variable (Measured as changes in values from year $t-1$ to $t$.) } \\
\hline Repurch & Stock Repurchase Ratio & Stock repurchases to book value of assets. \\
\hline \multicolumn{3}{|c|}{ Panel C: Regression Independent Variables (Measured as changes in values from year $t-2$ to $t-1$.) } \\
\hline Inst & Institutional Ownership & The fraction of shares owned by institutions. \\
\hline$q$ & Investment Opportunities & Market value of assets to the book value of assets \\
\hline Debt & Debt Ratio & Debt to assets. \\
\hline Turnover & Stock Turnover & Firm common stock turnover. \\
\hline LifeCycle & Firm Life-cycle & The ratio of retained earnings to total equity. \\
\hline MktCap & Market Capitalization & The dollar market value of common stock in millions. \\
\hline$R O A$ & Return on Assets & $\begin{array}{l}\text { Earnings before interest and taxes divided by total } \\
\text { assets. }\end{array}$ \\
\hline Insider & Insider Ownership & The fraction of shares owned by insiders. \\
\hline Insider 2 & Insider Ownership Squared & The squared value of Insider. \\
\hline Revenue & Revenue & The logarithm of firm revenue. \\
\hline
\end{tabular}

I use fixed effects regressions on changes in dependent variables from year $t-1$ to $t$ on changes in independent variables from $t-2$ to $t-1$ to establish causality. Firm fixed effect regressions control for all stable characteristics of a firm including industry and unmeasured characteristics. I also use yearly dummy variables to control for time-varying omitted characteristics. The use of firm fixed effects with yearly dummy variables limit endogeneity issues with my analysis. The use of yearly dummy variables and fixed effects creates what is effectively an intercept for each firm for each year. These intercepts are an average value of the unobserved fixed effects for each firm-year. These intercept values are not relevant to my analysis and thus are not reported in my results.

I add robustness to my results and address potential endogeneity more fully by using a difference generalized method of moments (GMM) methodology based on the Holtz-Eakin, Newey, \& Rosen (1988) methodology with refinements and validity tests developed by Arellano \& Bond (1991). I use the Stata command xtabond2 to implement the methodology. This command and its proper implementation are described by its developer in great detail in Roodman (2009).

The difference GMM methodology is particularly useful in panel samples with a limited number of time periods and a large number of firms such as my sample which consists of a maximum of 16 years of data for over 10,000 firms. Difference GMM uses lagged values of the dependent and independent variables of interest as instruments and removes fixed effects. It avoids endogeneity problems associated with autocorrelation in the dependent variable and with the inclusion of lagged independent variables. Difference GMM is used in many noteworthy papers including 
Cunat (2007), Brossard et al. (2013), and Brown, Fazzari, \& Petersen (2009). Almeida, Campello, \& Galvao (2010) find that the results of difference GMM conform to theoretical expectations in regressions using sample data that contains firm-fixed effects and heteroskedasticity.

Difference GMM uses lagged endogenous regressors as instruments which shrinks the dataset size because at least one year of data has to be dropped for each firm. In my implementation, only one year has to be dropped for each firm.

The dependent variables in my regressions depend on past realizations because current repurchase policy is largely dependent on past repurchase policy. In my robustness checks that use difference GMM, the independent variables of interest are assumed to be endogenous. In fact, the main purpose of my difference GMM robustness checks is to control for the potential (and likely) endogenous relationship between repurchase policy and institutional ownership.

My implementation of difference GMM results in the model shown in equation (1).

$$
\Delta \text { Policy }_{i t}=\Delta \text { Policy }_{i t-1}+\Delta \text { Inst }_{i t-1}+\beta \bullet \Delta \text { Control }_{i t-1}+\Delta \varepsilon_{i t}
$$

In this model, Policy $_{\mathrm{it}}$ represents the change in the firm repurchase policy. Policy ${ }_{\mathrm{it}-1}$ represents the change in firm repurchase policy in the previous year. The independent variable Inst $t_{\mathrm{it}-1}$ represents the change in institutional ownership percentage in the previous year. Control ${ }_{i t-l}$ represents a vector of time-varying firm level control variables. Year dummies are included as control variables to remove time-related shocks that affect all firms. The $\varepsilon_{\text {it }}$ term represents a time-varying observation-specific error term. The difference GMM methodology uses first-differences thus removing the firm-fixed effects because they are time invariant.

Table 2. Summary statistics

\begin{tabular}{|c|c|c|c|c|c|c|}
\hline \multicolumn{7}{|c|}{ Panel A: All Firms } \\
\hline Years & $N$ & Inst & MktCap & LifeCycle & $q$ & CashFlow \\
\hline $1990-1997$ & 37492 & $\begin{array}{c}28.9 \% \\
(23.6 \%)\end{array}$ & $\begin{array}{l}2106 \\
(163)\end{array}$ & $\begin{array}{l}-0.69 \\
(0.29)\end{array}$ & $\begin{array}{c}2.81 \\
(1.85)\end{array}$ & $\begin{array}{c}-0.16 \\
(0.01)\end{array}$ \\
\hline $1998-2005$ & 42398 & $\begin{array}{l}33.3 \% \\
(25.8 \%)\end{array}$ & $\begin{array}{l}4891 \\
(350)\end{array}$ & $\begin{array}{l}-0.53 \\
(0.18)\end{array}$ & $\begin{array}{c}4.68 \\
(1.86)\end{array}$ & $\begin{array}{l}-0.39 \\
(0.01)\end{array}$ \\
\hline Total & 79890 & $\begin{array}{c}31.3 \% \\
(24.6 \%)\end{array}$ & $\begin{array}{l}3603 \\
(239) \\
\end{array}$ & $\begin{array}{l}-0.61 \\
(0.24)\end{array}$ & $\begin{array}{c}3.81 \\
(1.85)\end{array}$ & $\begin{array}{l}-0.28 \\
(0.01)\end{array}$ \\
\hline \multicolumn{7}{|c|}{ Panel B: Firms with a Payout } \\
\hline $1990-1997$ & 13934 & $\begin{array}{c}37.9 \% \\
(38.0 \%)\end{array}$ & $\begin{array}{l}4858 \\
(547)\end{array}$ & $\begin{array}{c}0.46 \\
(0.64)\end{array}$ & $\begin{array}{c}2.07 \\
(1.75)\end{array}$ & $\begin{array}{c}0.03 \\
(0.04)\end{array}$ \\
\hline $1998-2005$ & 15716 & $\begin{array}{c}42.8 \% \\
(43.9 \%)\end{array}$ & $\begin{array}{l}10806 \\
(1,146)\end{array}$ & $\begin{array}{l}-1.49 \\
(0.57)\end{array}$ & $\begin{array}{c}2.22 \\
(1.75)\end{array}$ & $\begin{array}{c}0.02 \\
(0.04)\end{array}$ \\
\hline Total & 29650 & $\begin{array}{c}40.5 \% \\
(40.4 \%) \\
\end{array}$ & $\begin{array}{l}8030 \\
(816) \\
\end{array}$ & $\begin{array}{l}-0.57 \\
(0.61)\end{array}$ & $\begin{array}{c}2.15 \\
(1.75) \\
\end{array}$ & $\begin{array}{c}0.02 \\
(0.04) \\
\end{array}$ \\
\hline \multicolumn{7}{|c|}{ Panel C: All Firms } \\
\hline Years & Div & Repurch & PayIncr & PayDecr & RepIncr & RepDecr \\
\hline $1990-1997$ & $0.81 \%$ & $0.60 \%$ & $24.80 \%$ & $18.70 \%$ & $13.66 \%$ & $12.79 \%$ \\
\hline $1998-2005$ & $0.66 \%$ & $1.04 \%$ & $24.57 \%$ & $20.65 \%$ & $17.56 \%$ & $16.58 \%$ \\
\hline Total & $0.73 \%$ & $0.83 \%$ & $24.67 \%$ & $19.78 \%$ & $15.82 \%$ & $14.89 \%$ \\
\hline \multicolumn{7}{|c|}{ Panel D: Firms with a Payout } \\
\hline $1990-1997$ & $2.21 \%$ & $1.64 \%$ & $65.60 \%$ & $33.06 \%$ & $35.82 \%$ & $21.84 \%$ \\
\hline $1998-2005$ & $1.80 \%$ & $2.82 \%$ & $64.70 \%$ & $34.83 \%$ & $45.65 \%$ & $26.90 \%$ \\
\hline Total & $2.00 \%$ & $2.26 \%$ & $65.10 \%$ & $34.04 \%$ & $41.29 \%$ & $24.66 \%$ \\
\hline
\end{tabular}

Panels A and B, show means on the first row and medians in parentheses on the second row. In Panels C and D, means are shown.

I was able to use the first lag of independent policy and institutional variables in all my regressions as an instrument. I use two tests of model validity which are recommended by Roodman (2009): the Hansen-Sargan $J$-test and the Arellano-Bond test for second-order autocorrelation in differenced residuals. For both tests, a higher $p$-value indicates a valid model while $p$-values of less than 0.10 indicate an invalid model. AR(1) autocorrelation in 
differenced residuals is expected. The Arellano-Bond test for second-order autocorrelation is important because $\mathrm{AR}(2)$ autocorrelation indicates an invalid model. Therefore, I do not use any models in which the null hypothesis of no $\operatorname{AR}(2)$ autocorrelation is rejected at the $10 \%$ level.

\subsection{Summary Statistics}

Table 2 displays selected firm characteristics for my sample. Panel A includes all firms and panel B includes only firms that have a payout (either dividends or stock repurchases or both). Data is presented for the entire time period and for an early period, 1990 - 1997, and late period, 1998 - 2005. I perform analysis on the entire time period and the earlier and later time periods separately for robustness. Means and medians (shown in parentheses below) are displayed.

There are some notable patterns in the statistics. Institutional investors (Inst) percentage ownership increases from the early period to the late period. Firm size (MktCap) and $q$ also increase over time. The proxy for firm life-cycle (LifeCycle), retained earnings to total equity, is negative except for in the 1990 - 1997 time frame for firms with a payout. In contrast, the median is positive in all cases. This skewness is a result of some firms with a large negative value for this variable. Firms with a payout tend to be larger with a lower $q$ and higher institutional ownership than firms without a payout.

Summary statistics for payout-related variables are shown in Panels C and D. Medians are zero for almost all of the variables. Therefore, only means are shown. Unsurprisingly, all payout variables are higher in the sample (Panel D) that only includes firms with a payout. Consistent with (Fama \& French, 2001), dividends to assets (Div) goes down over time as repurchases to assets (Repurch) goes up. More firms increase total payouts (PayIncr) in comparison to firms that decrease total payouts (PayDecr). Similarly, increases in repurchases (RepIncr) are more common than decreases in repurchases (RepDecr).

Correlations for selected firm variables are displayed in Table 3. An asterisk marks correlations that are significant at the $5 \%$ level.

Table 3. Correlations

\begin{tabular}{|c|c|c|c|c|c|c|}
\hline & Payout & Repurch & Inst & MktCap & LifeCycle & $q$ \\
\hline Repurch & $0.6528^{*}$ & & & & & \\
\hline Inst & $0.0801 *$ & $0.0957^{*}$ & & & & \\
\hline MktCap & $0.0539 *$ & $0.0332 *$ & $0.0865^{*}$ & & & \\
\hline LifeCycle & 0.0008 & 0.0004 & 0.0013 & 0.0009 & & \\
\hline$q$ & -0.0025 & -0.0023 & $-0.0135^{*}$ & -0.0019 & 0.0013 & \\
\hline CashFlow & 0.0032 & 0.0024 & $0.0232 *$ & 0.0023 & -0.0008 & $-0.4194^{*}$ \\
\hline
\end{tabular}

* indicates two-tailed significance at $5 \%$.

\section{The Effect of Institutional Owners on Stock Repurchases}

The adverse selection model predicts that an increase in current institutional ownership will lead to an increase in future repurchases. Institutional ownership levels and stock repurchase levels have an endogenous relationship. Therefore, I test the effect that changes in institutional ownership have on subsequent changes in repurchases.

To test the influence that institutional owners have on future repurchases, the following firm and year fixed effects model is estimated.

$$
\text { Rpurch }_{i t}=\text { Year }_{t}+\text { Firm }_{i}+\text { Inst }_{i t-1}+\beta \bullet \text { Control }_{i t-1}+\varepsilon_{i t}
$$

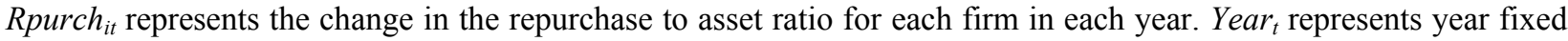
effects and firm fixed effects are represented by Firm $_{i}$. Inst $t_{\mathrm{it}-1}$ is the percentage of the firm's shares owned by institutional investors. Control $l_{i-1}$ is a vector of time-varying firm level control variables which consists of: $q$, debt, stock turnover, retained earnings to total equity, log of market capitalization, ROA, insider ownership, insider ownership squared, and $\log$ of revenue. The error term is denoted by $\varepsilon_{i t}$.

The independent variables are quantified as the change from year $t-2$ to year $t-1$. The dependent repurchase variable is quantified as the change from year $t-1$ to year $t$.

Table 4 reports on the effect that changes in institutional ownership have on stock repurchases (Repurch) in the subsequent year. The first regression only uses the control variables as independent variables. The statistically significant coefficients indicate that repurchases increase as $q$ decreases, debt decreases, retained earnings to total 
equity decreases, market capitalization increases, and return on assets decreases. The results for the control variables remain largely consistent throughout the rest of the regressions shown in the table.

Table 4. Institutional ownership and stock repurchases

(1)

\begin{tabular}{|c|c|c|c|c|}
\hline & All Firms & All Firms & $\begin{array}{c}\text { No } \\
\text { Repurchase } \\
\text { at year } t-2\end{array}$ & $\begin{array}{l}\text { Repurchase } \\
\text { at year } t-2\end{array}$ \\
\hline & Repurch & Repurch & Repurch & Repurch \\
\hline Inst & & $\begin{array}{c}0.0104^{* * *} \\
(3.15)\end{array}$ & $\begin{array}{c}0.0098^{* * *} \\
(3.16)\end{array}$ & $\begin{array}{c}0.0220^{*} \\
(1.66)\end{array}$ \\
\hline$q$ & $\begin{array}{c}-0.0004 * * * \\
(3.03)\end{array}$ & $\begin{array}{c}-0.0003^{* * *} \\
(2.96)\end{array}$ & $\begin{array}{c}-0.0002^{* *} \\
(2.20)\end{array}$ & $\begin{array}{c}-0.0108 * * * \\
(4.69)\end{array}$ \\
\hline Debt & $\begin{array}{c}-0.0099 * * * \\
(2.99)\end{array}$ & $\begin{array}{c}-0.0099 * * * \\
(2.92)\end{array}$ & $\begin{array}{c}-0.0057^{* *} \\
(2.21)\end{array}$ & $\begin{array}{c}-0.2002 * * * \\
(5.31)\end{array}$ \\
\hline Turnover & $\begin{array}{c}0.0000 \\
(0.68)\end{array}$ & $\begin{array}{c}-0.0000 \\
(0.43)\end{array}$ & $\begin{array}{c}0.0000 \\
(0.49)\end{array}$ & $\begin{array}{c}-0.0046^{* * *} \\
(2.97)\end{array}$ \\
\hline LifeCycle & $\begin{array}{c}-0.0000^{* *} \\
(2.51)\end{array}$ & $\begin{array}{c}-0.0000^{* * * *} \\
(2.75)\end{array}$ & $\begin{array}{c}-0.0000 \\
(0.47)\end{array}$ & $\begin{array}{c}-0.0000^{* *} \\
(1.97)\end{array}$ \\
\hline MktCap & $\begin{array}{c}0.0066^{* * *} \\
(6.41)\end{array}$ & $\begin{array}{c}0.0058^{* * *} \\
(6.83)\end{array}$ & $\begin{array}{c}0.0035^{* * *} \\
(4.24)\end{array}$ & $\begin{array}{c}0.0527 * * * \\
(7.56)\end{array}$ \\
\hline$R O A$ & $\begin{array}{c}-0.0011^{* *} \\
(2.27)\end{array}$ & $\begin{array}{c}-0.0011^{* *} \\
(2.34)\end{array}$ & $\begin{array}{c}-0.0005 \\
(1.54)\end{array}$ & $\begin{array}{c}-0.0647 * * * \\
(4.97)\end{array}$ \\
\hline Insider & $\begin{array}{c}-0.0110 \\
(1.51)\end{array}$ & $\begin{array}{c}-0.0119 \\
(1.62)\end{array}$ & $\begin{array}{c}-0.0045 \\
(0.86)\end{array}$ & $\begin{array}{c}-0.0557 \\
(1.47)\end{array}$ \\
\hline Insider2 & $\begin{array}{l}0.0085 \\
(1.12)\end{array}$ & $\begin{array}{l}0.0094 \\
(1.23)\end{array}$ & $\begin{array}{l}0.0076 \\
(1.37)\end{array}$ & $\begin{array}{l}0.0404 \\
(1.02)\end{array}$ \\
\hline Revenue & $\begin{array}{c}-0.0010 \\
(0.93)\end{array}$ & $\begin{array}{c}-0.0011 \\
(1.02)\end{array}$ & $\begin{array}{c}-0.0020 \\
(1.64)\end{array}$ & $\begin{array}{c}-0.0044 \\
(0.72)\end{array}$ \\
\hline Observations & 45611 & 45126 & 34083 & 11043 \\
\hline Firms & 7801 & 7778 & 7525 & 3588 \\
\hline R-squared & 0.05 & 0.19 & 0.33 & 0.25 \\
\hline
\end{tabular}

This table reports estimates of firm and year fixed effect regressions of changes (from year $t-1$ to $t$ ) in repurchases divided by book value of assets (Repurch). All independent variable values are calculated as changes in that independent variable from year $t-2$ to $t-1$. Regressions (1) and (2) include all firms. Regression (3) includes only firms that had no payout in year $t-2$ and regression (4) includes only firms that had a payout in year $t-2$.

In the second regression, I add a variable (Inst) representing the change in total institutional ownership. There is a positive and significant relationship between institutional ownership and subsequent stock repurchases.

Institutional owners prefer to own firms that repurchase stock. Therefore, the results in the second regression could be influenced by the tendency of institutional investors to invest more in firms that have repurchased stock previously. To alleviate that influence, the third regression is ran only on firms that did not have a repurchase in year $t-2$. The third regression demonstrates that institutional owners have a significantly positive influence on future stock repurchases in firms that did not repurchase stock in the previous year. The fourth regression shows that institutional owners encourage higher repurchases in firms that had repurchases in the previous year.

In Table 4, the sum of the number of firms in the third and fourth regression is greater than the number of firms in the first regression. This apparently odd result can be explained by the fact that many firms are included in both the third and fourth regression because in some years they had a repurchase in year $t-2$ while in other years they do not. 
Table 5. Institutional ownership, repurchases, and firm life-cycle

(1)

\begin{tabular}{lccc} 
& Early & Middle & Late \\
& LifeCycle & LifeCycle & LifeCycle \\
\hline Repurch & Repurch & Repurch \\
\hline Inst & $0.0131^{* *}$ & $0.0058^{*}$ & 0.0216 \\
\multicolumn{1}{c}{$q$} & $(2.01)$ & $(1.94)$ & $(1.48)$ \\
& -0.0004 & $-0.0009^{* * *}$ & $-0.0003^{*}$ \\
Debt & $(1.23)$ & $(4.85)$ & $(1.79)$ \\
& -0.0025 & $-0.0298^{* * *}$ & $-0.0071^{*}$ \\
Turnover & $(0.63)$ & $(6.01)$ & $(1.96)$ \\
& -0.0001 & $-0.0006^{* * *}$ & $-0.0039^{*}$ \\
LifeCycle & $(0.42)$ & $(3.03)$ & $(1.67)$ \\
& $-0.0000^{* * *}$ & 0.0001 & -0.0000 \\
MktCap & $(2.68)$ & $(0.63)$ & $(0.77)$ \\
& 0.0020 & $0.0077 * * *$ & $0.0173 * * *$ \\
ROA & $(1.48)$ & $(6.19)$ & $(5.02)$ \\
& 0.0005 & 0.0026 & $-0.0014^{* *}$ \\
Insider & $(0.25)$ & $(0.45)$ & $(2.13)$ \\
& 0.0093 & -0.0017 & $-0.0457^{*}$ \\
Insider2 & $(0.96)$ & $(0.23)$ & $(1.83)$ \\
& -0.0117 & 0.0016 & 0.0346 \\
Revenue & $(0.83)$ & $(0.19)$ & $(1.45)$ \\
Observations & -0.0015 & -0.0018 & -0.0005 \\
Number of Firms & $(0.89)$ & $(0.60)$ & $(0.29)$ \\
R-squared & 11505 & 18633 & 14988 \\
\hline Robust t statistics in parentheses & 4730 & 3093 \\
$*$ significant at $10 \% ; *$ significant at 5\%; & $* * *$ significant at $1 \%$ \\
\hline
\end{tabular}

This table reports estimates of firm and year fixed effect regressions of changes (from year $t-1$ to $t$ ) in repurchases divided by book value of assets (Repurch). All independent variable values are calculated as changes in that independent variable from year $t-2$ to $t-1$. Sample firms used in regressions (1), (2), and (3) include only Early, Middle and Late LifeCycle firms, respectively. The Early, Middle and Late LifeCycle groups include the Earliest three, Middle four, and Latest three LifeCycle deciles from year $t-1$, respectively. Deciles are formed on a yearly basis.

Adverse selection theory predicts that institutional investors will use their influence to persuade management to increase repurchases. Additionally, the theory predicts that institutional investors will find repurchases more attractive as information asymmetry increases. I test this prediction using retained earnings to total equity (LifeCycle) as a proxy for information asymmetry. DeAngelo et al. (2006) use this measure as a proxy for firm life-cycle. They assert that this is a valid proxy for firm information asymmetry. This relationship between firm life-cycle and information asymmetry seems logical because the further along a firm is in its life-cycle the more information an investor will have about the firm to judge its prospects, all else being equal. Additionally, as shown in Table 3, retained earnings to total equity is not significantly correlated to institutional ownership in my sample. Other proxies for information asymmetry such as market capitalization or analyst following are highly correlated to institutional ownership limiting their usefulness in my analysis.

I sort the sample of firms each year into information asymmetry deciles. I assign each firm-year to one of three groups. Firms in the bottom three deciles (Early LifeCycle) have high information asymmetry, those in the next four deciles (Middle LifeCycle) have moderate information asymmetry, and those in the highest three deciles (Late LifeCycle) have low information asymmetry. 
Table 6. Repurchases and time period

(1) (2)

\begin{tabular}{lcc} 
& $1990-1997$ & $1998-2005$ \\
\hline Inst & Repurch & Repurch \\
\multicolumn{1}{c}{$q .0065^{*}$} & $0.0152^{* * *}$ \\
\multicolumn{1}{c}{ Debt } & $(1.89)$ & $(2.87)$ \\
& -0.0000 & $-0.0006^{* * *}$ \\
Turnover & $(0.29)$ & $(4.64)$ \\
& $-0.0279^{* * *}$ & $-0.0079^{* *}$ \\
LifeCycle & $(4.46)$ & $(2.49)$ \\
& -0.0000 & $-0.0010^{* *}$ \\
MktCap & $(1.52)$ & $(2.56)$ \\
& 0.0000 & $-0.0000^{* * *}$ \\
ROA & $(0.78)$ & $(2.60)$ \\
& $0.0038^{* * *}$ & $0.0077^{* * *}$ \\
Insider & $(4.44)$ & $(6.12)$ \\
& $-0.0020^{*}$ & $-0.0016^{* * *}$ \\
Insider2 & $(1.67)$ & $(2.85)$ \\
& -0.0087 & -0.0156 \\
Revenue & $(1.16)$ & $(1.31)$ \\
& 0.0117 & 0.0085 \\
Observations & $(1.53)$ & $(0.65)$ \\
Firms & $0.0014^{*}$ & -0.0017 \\
R-squared & $(1.72)$ & $(1.13)$ \\
\hline Absolute & 17721 & 27405 \\
& 4813 & 6157 \\
& 0.11 & 0.26 \\
\hline
\end{tabular}

Absolute value of $\mathrm{t}$ statistics in parentheses

$*$ significant at $10 \%$;* significant at $5 \%$;** significant at $1 \%$

This table reports estimates of firm and year fixed effect regressions of changes (from year $t-1$ to $t$ ) in repurchases divided by book value of assets (Repurch) by time period. All independent variable values are calculated as changes in that independent variable from year $t-2$ to $t-1$. Regression (1) includes the years from 1990 to 1997. Regression (2) includes the years from 1998 to 2005.

Table 7. Repurchases and firm life-cycle (GMM)

(1)

\begin{tabular}{lc} 
& All Firms \\
\hline \multirow{2}{*}{ Inst } & Repurch \\
& $0.0181^{* *}$ \\
Repurch & $(2.08)$ \\
& $0.0665^{* *}$ \\
\multicolumn{1}{c}{$q$} & $(2.31)$ \\
& -0.0014 \\
Debt & $(0.87)$ \\
& -0.0677 \\
Turnover & $(1.34)$ \\
& -0.0000 \\
LifeCycle & $(0.14)$ \\
& -0.0001
\end{tabular}

(2)

Early LifeCycle Repurch

(2.00)

$-0.0161$

(0.27)

0.0029

(1.12)

$-0.0097$

$(0.22)$

0.0000

(0.48)

0.0000
(3)

Late LifeCycle

Repurch
0.0090
$(1.03)$
$0.0553 * *$
$(2.00)$
0.0029
$(1.01)$
-0.0348
$(0.76)$
0.0000
$(0.19)$
0.0000




\begin{tabular}{lccc} 
& $(0.98)$ & $(0.16)$ & $(0.18)$ \\
MktCap & -0.0014 & $-0.0317^{*}$ & -0.0031 \\
& $(0.12)$ & $(1.68)$ & $(0.22)$ \\
ROA & -0.0125 & -0.0049 & 0.0282 \\
& $(0.43)$ & $(0.20)$ & $(1.25)$ \\
Insider & -0.0948 & -0.0864 & -0.0790 \\
& $(1.17)$ & $(0.85)$ & $(0.66)$ \\
Insider2 & 0.0714 & 0.0970 & 0.1026 \\
& $(0.64)$ & $(0.62)$ & $(0.53)$ \\
Revenue & $-0.0492^{* * *}$ & 0.0252 & $-0.0916^{* * *}$ \\
& $(3.59)$ & $(1.16)$ & $(3.65)$ \\
Observations & 35430 & 15167 & 20981 \\
Number of Firms & 6823 & 4359 & 4285 \\
Chi2 $(p$-value) & 0.000 & 0.000 & 0.000 \\
$J p$-value & 0.140 & 0.902 & 0.466 \\
AR(2) $p$-value & 0.404 & 0.349 & 0.458 \\
Inst lag limits & 3 & 3 & 3 \\
Repurch lag limits & None & 3 & None \\
\hline
\end{tabular}

Robust z statistics in parentheses

$*$ significant at $10 \% ; * *$ significant at $5 \% ; * * *$ significant at $1 \%$

This table reports estimates generated by Arellano-Bond difference GMM of changes (from year $t-1$ to $t$ ) in repurchases divided by book value of assets (Repurch). All independent variable values are calculated as changes in that independent variable from year $t-2$ to $t-1$. Sample firms used in regressions (2) and (3) include only Early and Late LifeCycle firms, respectively. The Early and Late LifeCycle groups include the lowest and highest five LifeCycle deciles from year $t-1$, respectively. Deciles are formed on a yearly basis. $J$ is the Hansen-Sargan test of overidentifying restrictions. AR(2) is the Arellano-Bond test of second-order autocorrelation in the errors. Independent variables Inst and Repurch are instrumented using GMM-type instrument lags. All available lags are used unless validity tests are rejected, in which case lags are restricted to the highest number of lags which produce a valid model.

I then run regressions using the firm and year fixed effects model (2) that show the effect that changes in institutional ownership have on repurchases in the subsequent year. Regressions are run on the high, moderate, and low information asymmetry groups separately based on which group a firm is in during year $t-1$. The results are shown in Table 5 .

The first two regressions show that institutional investors encourage increased repurchases in firms with high and moderate information asymmetry. The third regression shows a statistically weak positive relationship between institutional ownership and future stock repurchases in low information asymmetry firms. It is notable that the Inst coefficient for the low information asymmetry firms group is higher than for the other two groups despite not being statistically significant. This may be explained by the higher propensity of firms with low information asymmetry to make repurchases. This higher propensity is shown in the average repurchase to asset ratios for the three groups (not shown): high information asymmetry $(0.36 \%)$, moderate information asymmetry $(0.64 \%)$, and low information asymmetry $(1.55 \%)$. The results shown in this table provide evidence that supports the adverse selection theory.

Table 6 and Table 7 display results that provide robustness to my results and further evidence for the adverse selection theory. Table 6 demonstrates that an increase in institutional ownership precedes a subsequent increase in stock repurchases in both the 1990 - 1997 and 1998 - 2005 time periods.

To generate the difference GMM analysis shown in Table 7, I create Early and Late LifeCycle groups which include the lowest and highest five LifeCycle deciles from year $t-1$, respectively. Deciles are formed on a yearly basis. I only create two groups instead of the three used in earlier analysis because the difference GMM methodology needs a large number of firm-years to accommodate the use of lagged variables as instruments. The results displayed in Table 7 indicate that institutional investors encourage stock repurchases primarily in firms with higher information asymmetry.

Institutional investors use their influence to persuade management to increase repurchases. This relationship is more significant in firms with higher information asymmetry. This evidence provides support for the adverse selection 
theory which predicts that institutional owners encourage higher stock repurchases to gain an advantage over other less informed investors.

\section{Conclusion}

Institutional investors have an informational advantage over other investors and have the capability to be better monitors of corporate management than individual investors. The adverse selection theory of Barclay \& Smith (1988) and Brennan \& Thakor (1990) predicts that institutional investors will encourage repurchases, especially in firms with high information asymmetry. This prediction holds as higher institutional ownership causes firms to increase repurchases and this relationship is stronger in firms with higher information asymmetry. My results provide evidence that institutional investors influence corporate repurchase policy, especially in firms with high information asymmetry between informed and uninformed investors.

\section{References}

Aggarwal, R., Erel, I., Ferreira, M., \& Matos, P. (2011). Does governance travel around the world? Evidence from institutional investors. Journal of Financial Economics, 100(1), 154-181. http://dx.doi.org/10.1016/j.jfineco.2010.10.018

Almeida, H., Campello, M., \& Galvao, A. F. (2010). Measurement errors in investment equations. Review of Financial Studies, 23(9), 3279-3328. http://dx.doi.org/10.1093/rfs/hhq058

Arellano, M., \& Bond, S. (1991). Some tests of specification for panel data: Monte Carlo evidence and an application to employment equations. The Review of Economic Studies, 58(2), 277-297. http://dx.doi.org/10.2307/2297968

Banerjee, S., Gatchev, V. A., \& Spindt, P. A. (2007). Stock market liquidity and firm dividend policy. Journal of Financial and Quantitative Analysis, 42(02), 369-397. http://dx.doi.org/10.1017/S0022109000003318

Barclay, M. J., \& Smith, C. W. (1988). Corporate payout policy: Cash dividends versus open-market repurchases. Journal of Financial Economics, 22(1), 61-82. http://dx.doi.org/10.1016/0304-405X(88)90022-0

Bartov, E., Krinsky, I., \& Lee, J. (1998). Evidence on How Companies Choose between Dividends and Open-Market Stock Repurchases. Journal of Applied Corporate Finance, 11(1), 89-96. http://dx.doi.org/10.1111/j.1745-6622.1998.tb00080.x

Becht, M., Bolton, P., \& Röell, A. (2003). Corporate Governance and Control. In G. Constantinides, M. Harris, \& R. Stulz (Eds.), Handbook of the Economics of Finance (Vol. 1, pp. 1-109). Amsterdam, The Netherlands: North-Holland.

Bennett, J. A., Sias, R. W., \& Starks, L. T. (2003). Greener pastures and the impact of dynamic institutional preferences. Review of Financial Studies, 16(4), 1203-1238. http://dx.doi.org/10.1093/rfs/hhg040

Black, F. (1976). The Dividend Puzzle. Journal of Portfolio Management, 2(5), 5-8. http://dx.doi.org/10.3905/jpm.1976.408558\#sthash.C1PPFJ0I.dpuf

Brennan, M. J., \& Thakor, A. V. (1990). Shareholder Preferences and Dividend Policy. Journal of Finance, 45(4), 993-1018. http://dx.doi.org/10.1111/j.1540-6261.1990.tb02424.x

Brossard, O., Lavigne, S., \& Sakinç, M. E. (2013). Ownership structures and R\&D in Europe: the good institutional investors, the bad and ugly impatient shareholders. Industrial and Corporate Change, 22(4), 1031-1068. http://dx.doi.org/10.1093/icc/dtt018

Brown, J. R., Fazzari, S. M., \& Petersen, B. C. (2009). Financing innovation and growth: Cash flow, external equity, and the 1990s R\&D boom. The Journal of Finance, 64(1), 151-185. http://dx.doi.org/10.1111/j.1540-6261.2008.01431.x

Chemmanur, T. J., He, S., \& Hu, G. (2009). The role of institutional investors in seasoned equity offerings. Journal of Financial Economics, 94(3), 384-411. http://dx.doi.org/10.1016/j.jfineco.2008.12.011

Cornett, M. M., Marcus, A. J., Saunders, A., \& Tehranian, H. (2007). The impact of institutional ownership on corporate operating performance. Journal of Banking \& Finance, 31(6), 1771-1794. http://dx.doi.org/10.1016/j.jbankfin.2006.08.006

Cunat, V. (2007). Trade credit: suppliers as debt collectors and insurance providers. Review of Financial Studies, 20(2), 491-527. http://dx.doi.org/10.1093/rfs/hhl015

D'mello, R., \& Shroff, P. K. (2000). Equity undervaluation and decisions related to repurchase tender offers: An empirical investigation. The Journal of Finance, 55(5), 2399-2424. http://dx.doi.org/10.1111/0022-1082.00292

De Cesari, A., Espenlaub, S., Khurshed, A., \& Simkovic, M. (2012). The effects of ownership and stock liquidity on the timing of repurchase transactions. Journal of Corporate Finance, 18(5), 1023-1050. 
http://dx.doi.org/10.1016/j.jcorpfin.2012.06.004

DeAngelo, H., DeAngelo, L., \& Skinner, D. J. (2009). Corporate Payout Policy. Foundations and Trends in Finance, 3(2-3), 95-287.

DeAngelo, H., DeAngelo, L., \& Stulz, R. M. (2006). Dividend policy and the earned/contributed capital mix: a test of the life-cycle theory. Journal of Financial Economics, 81(2), 227-254. http://dx.doi.org/10.1016/j.jfineco.2005.07.005

Desai, M. A., \& Jin, L. (2011). Institutional tax clienteles and payout policy. Journal of Financial Economics, 100(1), 68-84. http://dx.doi.org/10.1016/j.jfineco.2010.10.013

Dlugosz, J., Fahlenbrach, R., Gompers, P., \& Metrick, A. (2006). Large blocks of stock: Prevalence, size, and measurement. Journal of Corporate Finance, 12(3), 594-618. http://dx.doi.org/10.1016/j.jcorpfin.2005.04.002

Elyasiani, E., \& Jia, J. (2010). Distribution of institutional ownership and corporate firm performance. Journal of Banking \& Finance, 34(3), 606-620. http://dx.doi.org/10.1016/j.jbankfin.2009.08.018

Fama, E. F., \& French, K. R. (2001). Disappearing dividends: changing firm characteristics or lower propensity to pay? Journal of Financial Economics, 60(1), 3-43. http://dx.doi.org/10.1016/S0304-405X(01)00038-1

Field, L. C., \& Lowry, M. (2009). Institutional versus individual investment in IPOs: The importance of firm fundamentals. Journal of Financial and Quantitative Analysis, 44(3), 489-516. http://dx.doi.org/10.1017/S0022109009990032

Gaspar, J.-M., Massa, M., Matos, P., Patgiri, R., \& Rehman, Z. (2013). Payout Policy Choices and Shareholder Investment Horizons*. Review of Finance, 17(1), 261-320. http://dx.doi.org/10.1093/rof/rfr040

Gillan, S. L., \& Starks, L. T. (2007). The Evolution of Shareholder Activism in the United States*. Journal of Applied Corporate Finance, 19(1), 55-73. http://dx.doi.org/10.1111/j.1745-6622.2007.00125.x

Graham, J. R., Harvey, C. R., \& Rajgopal, S. (2005). The economic implications of corporate financial reporting. Journal of accounting and economics, 40(1), 3-73. http://dx.doi.org/10.1016/j.jacceco.2005.01.002

Grinstein, Y., \& Michaely, R. (2005). Institutional holdings and payout policy. The Journal of Finance, 60(3), 1389-1426. http://dx.doi.org/10.1111/j.1540-6261.2005.00765.x

Grullon, G., \& Michaely, R. (2002). Dividends, share repurchases, and the substitution hypothesis. The Journal of Finance, 57(4), 1649-1684. http://dx.doi.org/10.1111/1540-6261.00474

Hadani, M., Goranova, M., \& Khan, R. (2011). Institutional investors, shareholder activism, and earnings management. Journal of Business Research, 64(12), 1352-1360. http://dx.doi.org/10.1016/j.jbusres.2010.12.004

Holtz-Eakin, D., Newey, W., \& Rosen, H. S. (1988). Estimating vector autoregressions with panel data. Econometrica: Journal of the Econometric Society, 56(6), 1371-1395.

Jensen, M. (1986). Agency cost of free cash flow, corporate finance, and takeovers. Corporate Finance, and Takeovers. American Economic Review, 76(2), 323-329.

Lintner, J. (1956). Distribution of incomes of corporations among dividends, retained earnings, and taxes. The American Economic Review, 46(2), 97-113.

Miller, M. H., \& Modigliani, F. (1961). Dividend policy, growth, and the valuation of shares. Journal of Business, 34(4), 411-433.

Moser, W. J. (2007). The effect of shareholder taxes on corporate payout choice. Journal of Financial and Quantitative Analysis, 42(4), 991. http://dx.doi.org/10.1017/S0022109000003471

Poterba, J. M., \& Summers, L. H. (1984). New Evidence That Taxes Affect the Valuation of Dividends. The Journal of Finance, 39(5), 1397-1415. http://dx.doi.org/10.1111/j.1540-6261.1984.tb04914.x

Renneboog, L., \& Trojanowski, G. (2011). Patterns in payout policy and payout channel choice. Journal of Banking \& Finance, 35(6), 1477-1490. http://dx.doi.org/10.1016/j.jbankfin.2010.10.028

Roodman, D. (2009). How to do xtabond2: An introduction to difference and system GMM in Stata. Stata Journal, 9(1), 86-136.

Shleifer, A., \& Vishny, R. W. (1986). Large shareholders and corporate control. The Journal of Political Economy, 94(3), 461-488.

Sulaeman, J. A. (2008). Essays on the impact of institutional investors on market efficiency and corporate policies. dissertation. University of Texas Graduate School. University of Texas. Austin. 